\title{
Rethinking Strategy for SMEE Support in the Light of the Entrepreneurial Ecosystem
}

\author{
Miroljub Hadzic ${ }^{a^{*}}$, Petar Pavlovic ${ }^{b}$ \\ ${ }^{a}$ Professor, Faculty of Business, University Singidunum, 29 Danijelova st., 11000 Belgrade, Serbia \\ ${ }^{b}$ Public Policy Secretariat, Government of the Republic of Serbia, 10 Vlajkoviceva st., 11000 Belgrade, Serbia
}

\begin{abstract}
Serbia has started transition in 2000. Although it experienced fast growth prior to the global economic crisis, critical number of SMEs was not created to achieve a sustainable development of entrepreneurial sector. During the crisis period SMEs faced with development limits, especially shops and micro companies. In the period 2009-2014 Serbian economy had zero rate of growth, the business climate was generally somewhat deteriorated and support to SMEE weakened by Government, local level of governance and financial institutions. There are positive signs of economic recovery of Serbia during 2015 and 2016. The market reforms got momentum in some important areas. The Government successfully put under control huge budget deficit and public debt. The inflation rate became for the first time low, similar to the European level. The Strategy for support SME, entrepreneurship and competitiveness in the period 2015-2020 was enacted at the end of 2014. Its importance became critical considering weaknesses of entrepreneurial sector, bottlenecks and limits of existing governmental measures for SMEE support. The point is to highlight those from the point of view of development the entrepreneurial ecosystem, as a new conceptual framework designed to foster economic development via entrepreneurship, innovation and small business growth.
\end{abstract}

Keywords:

Entrepreneurial Ecosystem;

SMEE;

Measures;

Support.

Article History:

Received: $07 \quad$ August 2019

Accepted: 22 October 2019

Published: $01 \quad$ December 2019

\section{1- Introduction}

Serbia has started market reform in 2000, as the last among countries of Central and Eastern Europe. Prior to the crisis it experienced fast development of the SMEE sector, due to overall improvement of business climate and supportive Government measures. In spite of the wish the critical number of new companies and shops did not achieved and the development of the SMEE sector did not became sustainable. The global economic crisis severely affected the economy, especially micro companies and shops. The business climate deteriorated, supportive measures weakened and also financial support. It seems that 2011 was the worst year, when more companies and shops were closed than started their activities. After the period 2009-2014 with zero rate of growth the national economy secured recovery. Additionally, the market reform got momentum in some important arrears.

Now, the overall development strategy and supportive measures to SMEE ought to be oriented more to the level of companies in order to improve their efficiency and competitiveness. The main development hindrances have to be overcome, like weak financial support, heavy fiscal duties, complicated fiscal and inspection procedures. In the light of the entrepreneurial ecosystem, as a new framework for SMEE support, the Strategy for support SME, entrepreneurship and competitiveness in the period 2015 -2020 has to be reexamined.

The aim of the paper is firstly, to envisage the current stage of development of Serbian SMEE, including strengths and limits and secondly, to evaluate the network of institutions responsible, development documents and current

\footnotetext{
* CONTACT: Mhadzic@ singidunum.ac.rs

DOI: http://dx.doi.org/10.28991/esj-2019-01201
}

(C) 2019 by the authors. Licensee ESJ, Italy. This is an open access article under the terms and conditions of the Creative Commons Attribution (CC-BY) license (https://creativecommons.org/licenses/by/4.0/). 
measures for SME support in the light of the entrepreneurial ecosystem as a new conceptual framework.

\section{2- The Economic Recovery is Secured}

After six years with zero rate of growth GDP real increase was positive in 2015 and $2016(0.8 \%$ and 2.8\%, respectively) with encouraging expectation for the next period (projection of 3\% and 3.5\% growth for 2017 and 2018). The economic recovery was registered due to the increase in domestic demand and somewhat in foreign one. The economic activity is higher $2.4 \%$ in comparison to pre-crisis period. Industrial production increased (4.7\%), also construction (9.3\% in the first three quarter of 2016), retail trade volume (7.5\%) and tourism (13\%). Volume of export increased in 2016 for $11.5 \%$ while import volume $6.1 \%$, with increasing cover of import by export (77\%). Foreign trade deficit was $4 \%$ of GDP and completely was covered by foreign direct investments (FDI amounted 1.8 and 1.6, billion $€$ in 2015 and 2016. respectively) [1].

Table 1. Serbia - main economic figures 2009-2016 [1].

\begin{tabular}{lcccccccc}
\hline & $\mathbf{2 0 0 9}$ & $\mathbf{2 0 1 0}$ & $\mathbf{2 0 1 1}$ & $\mathbf{2 0 1 2}$ & $\mathbf{2 0 1 3}$ & $\mathbf{2 0 1 4}$ & $\mathbf{2 0 1 5}$ & $\mathbf{2 0 1 6}$ \\
\hline GDP (\% p.a.) & -3.1 & 0.6 & 1.4 & -1.0 & 2.6 & -1.8 & 0.7 & 2.7 \\
\hline GDP $€$ bill & 30.7 & 29.8 & 33.4 & 31.7 & 34.3 & 33.3 & 32.9 & 33.8 \\
\hline GDP p.c. $€$ & 4.187 & 4.082 & 4.619 & 4.400 & 4.781 & 4.672 & 4.626 & 4.750 \\
\hline Inflation (\% p.a.) & 6.6 & 10.3 & 7.0 & 12.2 & 2.2 & 1.7 & 1.5 & 1.6 \\
\hline Current Account Deficit \%GDP & -6.6 & -6.8 & -10.9 & -11.6 & -6.1 & -6.0 & -4.8 & -4.0 \\
\hline Budget Deficit \%GDP & -4.4. & -4.6 & -4.8 & -6.8 & -5.5 & -6.6 & -3.7 & -1.7 \\
\hline Public Debt \%GDP & 32.8 & 41.8 & 45.4 & 56.2 & 59.6 & 70.4 & 74.7 & 72.9 \\
\hline External Debt \%GDP & 72.7 & 79.0 & 72.2 & 80.9 & 75.1 & 77.1 & 80.1 & 76 \\
\hline
\end{tabular}

After years the inflation rate became comparable to the EU level. In 2016 it was $1.6 \%$ (1.5 and $1.7 \%$ in 2014 and 2015). It was due to domestic factors - fiscal consolidation measures introduced and external factors - low oil prices and low agricultural prices. Moreover, it was lower than the target fixed by the Central Bank (National Bank of Serbia) $4 \pm 2 \%$. So, in meantime NBS decided to put down the target limit to $3 \pm 1.5 \%$. NBS also put down referent interest rate to $4 \%$ p.a., which is the continuation from the late 2013 during which the rate was decreased by $7.75 \mathrm{pp}$. The low inflation rate was important for foreign exchange stabilization as RSD was corrected by $3.5 \%$ only during the last four years. High level of foreign exchange reserves of NBS (10.2 billion $€$ ), the stand - by arrangement with IMF and improved the credit rating position (Moodys' improved Serbian position from B1 to Ba3) were important factors, as well [2].

It seems that Serbia put its main development bottlenecks under control. The Budget deficit in 2016 was $1.7 \%$ of GDP (6.6\% and 3.7\% in 2014 and 2015, respectively), much lower than projected. The fiscal consolidation was due to introduction of painful measures, like, on the one hand, the cut in wages in the public sector and pensions by $10 \%$ and, on the other hand, improved collecting of fiscal duties. In 2016 the total public debt, as the share in GDP, was 72.9\% (75\% in 2015), although the starting cut of the public debt was expected from 2017 on, as the program related to stand - by arrangement with IMF was stated. The total external debt, measured as its share in GDP, at the same time was 76\%, which is an encouraging improvement in comparison to its maximum (81\% at the end of 2013) [1].

\section{3- The Better Expectations by Entrepreneurs}

The market reforms got momentum in addition to the improved economic climate. According to the Doing Business Report for 2017 prepared by the World Bank, Serbia belongs to top ten leaders in market reforms, as it was ranked as the $47^{\text {th }}$ while it was the $54^{\text {th }}$ placed the year earlier. The main step forward was related to shorten and improved procedure for the construction permit (according to this Serbia improved its position from the $152^{\text {nd }}$ to the $36^{\text {th }}$ ). Also important steps were some improvements within the Land registry and the Agency for Business registers (Serbia moved from the $72^{\text {nd }}$ to the $56^{\text {th }}$ position and for the later from the $62^{\text {nd }}$ to the $42^{\text {nd }}$ position, respectively). At the same time complicated legal and administrative procedures were assessed as the main development hindrances (namely, a contractual execution and electricity permit) [3]. 


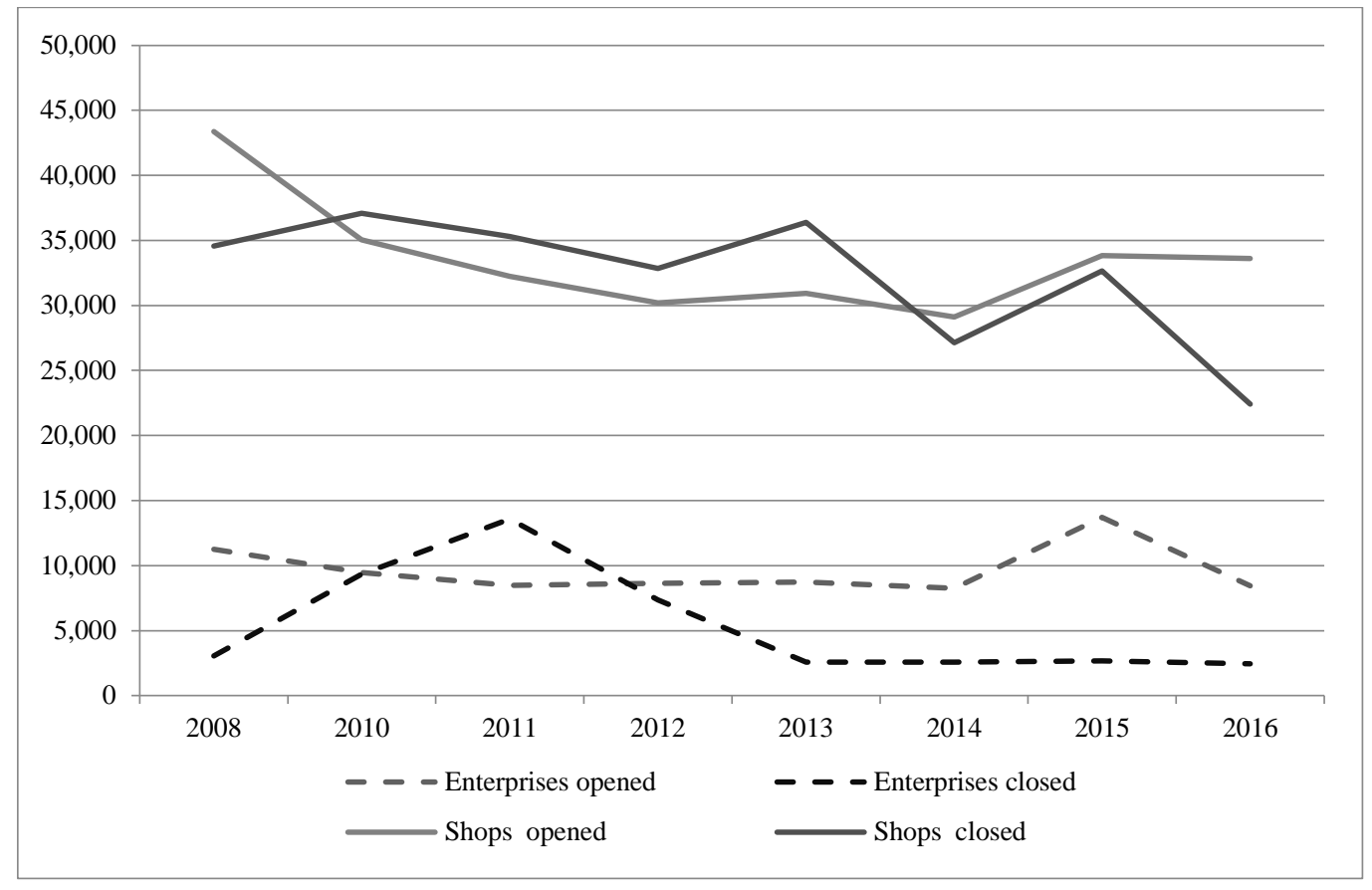

Figure 1. Serbia - Opened and closed companies and shops.

It seems that Serbian entrepreneurs felt more comfortable then before and, as the result, more and more companies and shops were started their business each year, while at the same time the trend of closing business was somewhat slower. During the crisis the worst was situation in 2011, when for the first time in the transition period more companies and shops were closed than newly established (a negative result of business demography) [4].

The investigation was made with one thousand entrepreneurs in companies and shops in order to prove that business environment is improved and consequently the expectations of entrepreneurs are better than before. The questionnaire was related to the business environment, business results and business plans. It compares 2012 and 2015 . As one can consider the businessmen are more optimist then before, as a result of the speeding reforms in the recent period. According to the investigation more entrepreneurs are expecting higher profit in the future (44\% and $34 \%$ in 2015 and 2012, respectively) and higher employment also (24\% and 19\%, respectively) [5].

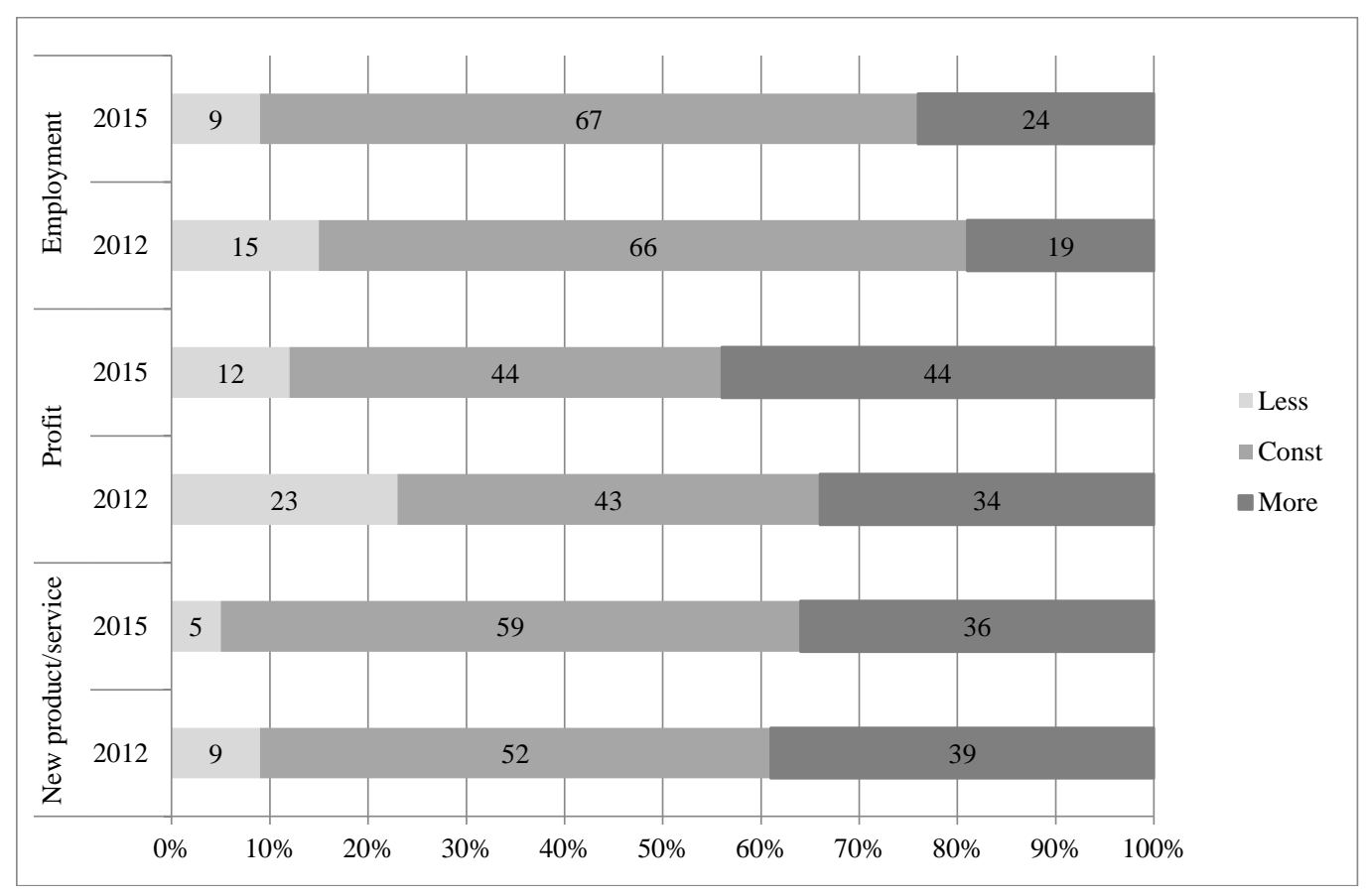

Figure 2. Serbia - Businessman's expectation. 


\section{4- The Reexamination of Government Measures and Strategic Documents}

The entrepreneurial ecosystem is a new conceptual framework designed to foster economic development via entrepreneurship, innovation and small business growth [6]. Among others it emphasized legal, bureaucratic and regulatory framework, which is by Serbian entrepreneurs assessed among the main limits for SMEE development. The combination of different financial models for financing is vital for the entrepreneurial ecosystem, while the finance is seen (by entrepreneurs, also) as a development hindrance. It also stresses that supportive measures have to be in line with local conditions, although they are predominantly of a general character $[7,8]$.

Another important issue, which was pointed by some experts, is the reexamination of the industrial policy. They criticized the industrial policy if it should pick winners only, as it can be accused for distorting competition. At the same time a new manner of an industrial policy is advised, by which clean investments are encouraging, investments into tradable and challenging fast growing economies, as well. This approach advocates the need for transformation of the national industry, competition policy strength and government activism. As a result, the reexamined industrial policy can produce more green economy, overcome the lack of the financial support, emphasize the importance of decentralization and give better outcome if it is implemented in competitive sector [9].

The production and services, manufacturing especially, are transformed dramatically with science - technology driven changes, as follows: rising productivity, outsourcing services, Global Value Chains, relocation of labor intensive operations, changes in the skill composition and other high potential invents [10]. The interesting analysis with policy recommendation was performed, with an aim to raise competitiveness of Serbian companies, including SMEs, through industrial policy. Serbian manufacturing has been stagnant during the transition period, mainly due to low investments and low value added (25\%). The steps which can change this related to the increase in investments in manufacturing as foreign direct investments (FDI) were oriented toward non - tradable sector [11] and to invest in order to close competitiveness gap (Serbian productivity in manufacturing is around $40 \%$ of those in Hungary, Czech Republic, Slovakia and Poland, while at the same time wages are lower in comparison to those countries). There are different possibilities to improve competiveness by the government active measures and at the same time on the level of companies, with a differentiation between large companies and SMEs. The Structural analysis was performed for Serbian industry in the period 2009-2015, based on Lyvesey's concept of relative industry maturity. The outcomes of the study are interesting and informative, especially for policy makers. Serbian industries according to their maturity were separated into four categories, as follows: Emerging (electric equipment, motor vehicles, rubber and plastic, wood); Still Growing (food, leather and textile); Shrinking (IT, metal production, furniture, Machinery) and Stagnant (metal, beverage, chemical, petrol product and tobacco). So, recommendations for policy makers can be summarized as follows: proactive FDI policy, including investments promotion and improving overall business conditions, and proactive SME policy with industrial policy elements targeted to support SME with potential [12]. Considering the general institutional instability and the lack of resources it seems that this targeted SME policy is more necessary [13]. It is worth noting that there is an intention to support education, training and IT start - ups with certain funds (10 million $€$ ), in line with the Operational plan for support IT sector in 2017.

Research, Development and Innovation (RDI) is by the middle - income and emerging economies seen as an important vehicle t to move up in global value chains, to escape "middle - income trap" and move toward a knowledge based economy [14]. RDI was recognized by all countries within the Region of South East Europe (SEE) as essentially important factor in order to improve world -wide competitiveness of their economies and during the transitory period considerable efforts were made. However, the look into the stage of RDI development estimated that SEE is below the EU average and far below their development needs. The general assessment tells us that the average score of the Region is 1.6 out of 5. It says that the countries in the Region started to shape RDI policies. It is important to note that Serbian score is higher than the average (2), which indicates that it adopted, but not implemented yet the whole framework. SEE countries already improved the use of limited R\&D sources, improved R\&D policy framework and recognize R\&D international cooperation as a priority. However, the challenges are still opened [15]. Firstly, RDI expenditures are very low, less than $0.5 \%$ of GDP in comparison to $2 \%$ of GDP in EU. Additionally, a small portion of R\&D comes from the private sector (12\% in comparison to the EU average of 54\%). There was a little coordination between institutions responsible for development of specific industries and different regions, between public and private sector in R\&D, as well. The Institutional infrastructure for $R \& D$ is not finished yet and strategic documents were not completed, as well. Essentially important is to strengthen the research base, as one of the main finding is that the research base is pure, among others, because of the brain drain process on the way from less developed countries generally, where SEE countries belong. Considering low level of the private $R \& D$ a recommendation of the study is, among others, to give incentives to the private $R \& D$ and to build infrastructure relevant for the sector. Within the framework of process of joining EU, Serbia has already started preparation of the Strategy for Research and Innovation for Smart Specialization (so called RIS3), where the point is to mark industries in which investments would results in the knowledge based growth [16]. 
The Spatial dimension of development is very important. Serbia for decades is suffering from the great and increasing regional discrepancies. Namely, the differences between regions are even more than 1:20, measuring by GDP p.c. During the transitory period those discrepancies were widen, due to the lack of the measures of the regional policy and the prevailing market forces in new investments, especially in foreign direct investments (FDI). So, one can recognize that the spatial development tends to be concentrated along with the European transport corridor X, from North to South (Subotica - Belgrade - Nis). Obviously, the analysis of the interrelation between industrial policy and regional policy has to emphasize the need to promote competitiveness of all regions. Serbia puts sector policies high of agenda of its industrial policies [15]. The Industrial Policy of Serbia in the period 2011 - 2020 was adopted as the strategic document, with two pillars: a) sector specific approach: strengthening of some specific sectors, like food production, automotive and metal industry; and b) increased attention to regional industrial development, with the establishment of regional industrial centers and infrastructures. The heavy concentration in R\&D activities was a problem highlighted, which limits the diffusion of knowledge. So, the R\&D mapping was suggested as a starting point. The discrepancies between sector strategies and other national policies, was recognized as an important challenge. It is important issue for investment incentives, when it comes to the investments location prioritization, because of conflicts between different stakeholders. In order to overcome the issue a closer inter-ministerial coordination and the involvement of all relevant regional stake-holder seems to be useful. The numerous of the national and regional strategic documents and plans were created during the time, with low level of coordination between each other, even with some mutual conflicts present. It asks for better coordination and more active approach by regional stake-holders. During the preparation of investment programs and plans regional actors are rarely or even not consulted at all, which asks for compulsory consultancy and more transparent processes. Even, it seems that regional stake-holders often do not understand how they can contribute to overall targets and aims in the industrial sector strategies. Instead, the plans and projections would be prepared and discussed on both the national and regional levels as well [16].

\section{5- Conclusion}

Serbia has secured its economic recovery from 2015 and one can expect respectable rate of growth during the next several years. Important for all economic subjects, but for SME essentially important, is to secure the continuation of market reforms, which got momentum in the recent period and together with higher internal and somewhat external demand produced more optimism among entrepreneurs and higher expectation for future, regarding productivity increase, employment and profitability, as well.

The entrepreneurial ecosystem, as a new conceptual framework was recently designed to foster economic development via entrepreneurship, innovation and small business growth. Considering low level of competitiveness of Serbian companies abroad, it is important to continue and strengthen government supportive measures for SME. In the future those measures have to be more oriented toward micro level, the level of companies and specific to the local and regional level. The Government FDI policy has to be proactive in order to reorient FDI more to manufacturing and tradable sectors and proactive SME policy with industrial policy elements. Serbia seems has created the RDI policy framework, but the point is firstly, to implement it fully and secondly, to overcome challenges, like low level of RDI expenditures in GDP and by putting incentives for the private RDI expenditure, to strengthen the research base and better coordinate activities of different institutions responsible, especially on the local and regional level. Regarding the spatial development and widened regional discrepancies it is relevant to coordinate industrial policy and regional policy in order to push up competitiveness of all regions, which asks for better inter - ministerial coordination and more active approach of local and regional stakeholders.

\section{6- Conflict of Interest}

The author declares that there is no conflict of interests regarding the publication of this manuscript. In addition, the ethical issues, including plagiarism, informed consent, misconduct, data fabrication and/or falsification, double publication and/or submission, and redundancies have been completely observed by the authors.

\section{7- References}

[1] Ministry of Finance of RS, “Current macroeconomic situation”, (February 2017).

[2] National Bank of Serbia, "Report on Inflation", (February 2017).

[3] World Bank, "Doing Business 2017: Equal Opportunity for All." Doing Business (October 25, 2016). doi:10.1596/978-1-46480948-4.

[4] Statistical Office of the Republic of Serbia, "Enterprises in the Republic of Serbia by size in 2016”, (2017).

[5] USAID, "Business Enabling Project”, Chamber of Commerce of RS, IPSOS Strategic Marketing, (2015).

[6] Mazzarol, Tim., "White Paper, Growing and sustaining entrepreneurial ecosystem: What they are and the role of government policy”, (2014), White Paper WP01-2014. 
[7] Stam E., Spigel B., "Entrepreneurial Ecosystem", Utrecht University, School of Economics, Discussion Paper Series 13-16, (2016), Available online: www.uu.nl/organisatie/utrecht-university-school-of-economicsuse/onderzoek/publicaties/discussionpapers/2016.

[8] Spigel, Ben, and Richard Harrison. "Toward a Process Theory of Entrepreneurial Ecosystems." Strategic Entrepreneurship Journal 12, no. 1 (November 21, 2017): 151-168. doi:10.1002/sej.1268.

[9] Aghion, Philippe, Julian Boulanger, and Elie Cohen. "Rethinking industrial policy." Bruegel Policy Brief 2011/04, June 2011." (2011).

[10] Kravchenko, Alla, and Iryna Kyzymenko. "The Forth Industrial Revolution: New Paradigm of Society Development or Posthumanist Manifesto.” Philosophy and Cosmology 22 (January 2019): 120-128. doi:10.29202/phil-cosm/22/10.

[11] Boljanovic, Srdjan, and Miroljub Hadzic. “Impact of Foreign Direct Investments on Serbian Industry.” Industrija 45, no. 3 (2017): 39-64. doi:10.5937/industrija45-13465.

[12] Pyke, Frank. "Managing Technological Change for Inclusive Growth.” Cambridge Journal of Economics 42, no. 6 (August 24, 2018): 1687-1695. doi:10.1093/cje/bey023.

[13] Pruzinsky P., "Raising Competitiveness through Industrial Policy", OECD SEE Regional Program, Belgrade, (2017) January 2017. Available online: http://vs3836.cloudhosting.rs/malodrvo/03_Industrial_Policy_OECD_Patrik_Pruzinsky.pdf.

[14] Zeković, S. "The contribution to the making of the new industrial policy of Serbia", in Proceedings of International scientific conference "Science, Education, Technology, Innovation", (2019), Belgrade: IRASA, Available online: http://raumplan.iaus.ac.rs/bitstream/id/1357/Zekovic_SETI_2019.pdf, pp. 399-410.

[15] Bailey, David, Christos Pitelis, and Philip R Tomlinson. "A Place-Based Developmental Regional Industrial Strategy for Sustainable Capture of Co-Created Value.” Cambridge Journal of Economics 42, no. 6 (July 9, 2018): 1521-1542. doi:10.1093/cje/bey019.

[16] A Policy Outlook, OECD, "Competitiveness and Private Sector Development, Competitiveness in South East Europe", (2016), Available online: https://read.oecd-ilibrary.org/development/competitiveness-in-south-east-europe/summary/english_a9126ab9en\#page1.

[17] OECD SEE Regional Program, "Strengthening Spatial Dimension in Manufacturing Sector Strategies", (January 2017), Available online: http://vs3836.cloudhosting.rs/malodrvo/04_Industrial_Policy_OECD_Umur_Gokce.pdf.

[18] Government of Serbia, "The Strategy for support SME, entrepreneurship and competitiveness in the period 2015 -2020”, (2014).

[19] Government of Serbia, “The Draft Strategy for Research and Innovation for Smart Specialization, (RIS3)”, (2016).

[20] Government of Serbia, "The Report on Competitiveness and Economic Development of RS” (2016).

[21] Government of Serbia, "The Action Plan for the Implementation of The Strategy for support SME, entrepreneurship and competitiveness in 2015 and the projection of 2016", (2014). 